\title{
Performance of nurses in the bed management service of a teaching hospital
}

\author{
Atuação de enfermeiros na gestão de leitos de um hospital de ensino \\ Actuación de enfermeros en la gestión de camas de un hospital - escuela
}

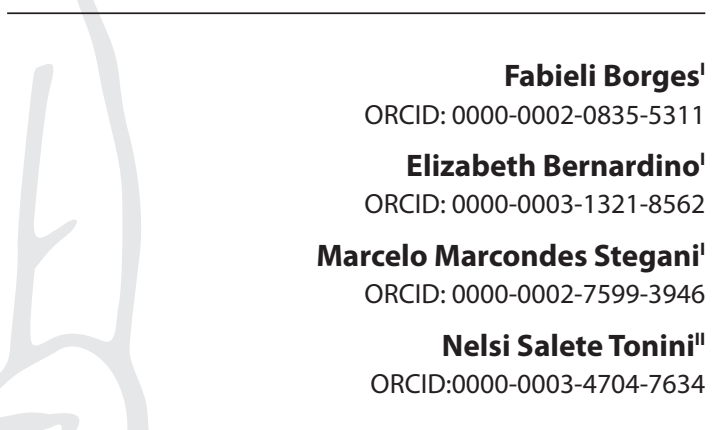

'Universidade Federal do Paraná. Curitiba, Paraná, Brazil. "Universidade Estadual do Oeste do Paraná. Cascavel,

Paraná, Brazil.

How to cite this article: Borges F, Bernardino E, Stegani MM, Tonini NS. Performance of nurses in the bed management service of a teaching hospital. Rev Bras Enferm. 2020;73(4):e20190349. doi: http://dx.doi.org/10.1590/0034-7167-2019-0349

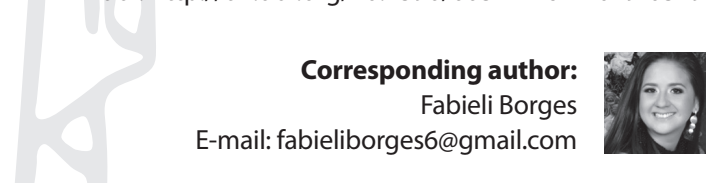

EDITOR IN CHIEF: Antonio José de Almeida Filho ASSOCIATE EDITOR: Hugo Fernandes

Submission: 05-01-2019

Approval: 09-17-2019

\begin{abstract}
Objectives: to analyze the performance of nurses in the Bed Management service of a public teaching hospital. Methods: descriptive, qualitative research inspired by Dubois theoretical model. 32 participants from the bed management unit and care units of a public hospital were interviewed from February to May 2018. Observations and data records from the Bed Management service complemented data collection. Theme/Category-Based Content Analysis was used. Results: the performance of nurses was described in three analysis matrices, represented by the categories: acquisition, implementation and maintenance of nursing resources; transformation of nursing resources into nursing service and results of the work of the nurse in Bed Management. Final Considerations: understanding the performance of nurses in bed management contributes to the scenario of new practices and different roles that favor visibility and strengthening of the nurse's identity.
\end{abstract}

Descriptors: Nurse's Role; Bed Occupancy; Hospital Bed Capacity; Health Management; Teaching Hospital.

\section{RESUMO}

Objetivos: analisar a atuação de enfermeiros na gestão de leitos de um hospital público de ensino. Métodos: trata-se de uma pesquisa descritiva, qualitativa, inspirada no modelo teórico de Dubois. Foram entrevistados 32 participantes da unidade de gestão de leitos e unidades assistenciais de um hospital público no período de fevereiro a maio de 2018. A observação e os registros de dados do serviço de Gestão de Leitos complementaram a coleta. Utilizou-se a Análise de Conteúdo Temático Categorial. Resultados: a atuação do enfermeiro foi desvelada em três matrizes de análise, representadas pelas categorias: aquisição, implementação e manutenção de recursos de enfermagem; transformação de recursos de enfermagem em serviços de enfermagem; e resultados do trabalho do enfermeiro da Gestão de Leitos. Considerações Finais: entender como a atuação de enfermeiros na Gestão de Leitos contribui no cenário de novas práticas e diferentes papéis em prol da visibilidade e fortalecimento da identidade do enfermeiro.

Descritores: Papel do Profissional de Enfermagem; Ocupação de Leitos; Leito Hospitalar; Gestão em Saúde, Hospital de Ensino.

\section{RESUMEN}

Objetivos: analizar la actuación de los enfermeros en la gestión de camas de un hospitalescuela público. Métodos: se trata de una investigación descriptiva, cualitativa, inspirada en el modelo teórico de Dubois. Se entrevistaron 32 participantes de la unidad de Gestión de Camas y de las unidades asistenciales de un hospital público, durante el período comprendido entre febrero y mayo de 2018. La observación y el registro de los datos del servicio de gestión de camas complementaron la recolección y para su clasificación, se utilizó el Análisis de Contenido Temático Categorial. Resultados: el desempeño del enfermero se reveló en tres matrices de análisis, representadas por las categorías: adquisición, implementación y mantenimiento de los recursos de enfermería; transformación de los recursos de enfermería en servicios de enfermería; y resultados del trabajo del enfermero en la Gestión de Camas. Consideraciones Finales: es evidente que el desempeño de los enfermeros en la gestión de camas contribuye con el escenario de nuevas prácticas y diferentes roles a favor de la visibilidad y el fortalecimiento de la identidad del enfermero.

Descriptores: Papel del Profesional de Enfermería; Ocupación de las Camas; Cama Hospitalaria; Gestión en Salud; Hospital-Escuela. 


\section{INTRODUCTION}

The issue of hospital beds is discussed all over the world, and overcrowding is a constant topic $\mathrm{c}^{(1-3)}$. This is due to the high demand and short supply of beds, which obstructs hospital admissions and increases the number of patients in emergency rooms or in the intensive care unit exit way, delaying the transference of discharged patients ${ }^{(4)}$.

Care or financial measures should be taken for the optimization of hospital beds, as the number of beds does not grow at the same rate as the demands of hospitalization ${ }^{(3)}$. There is a concern regarding the sustainability of the public health system and the improvement of bed-occupancy management. Changing, for example, the management policy of this sector, can improve patient flow and help achieving important results in this context ${ }^{(5-6)}$. In Brazil, the National Policy for Hospital Care (PNHOSP) established the Internal Regulation Center (NIR), with the objective of managing hospital beds and as a tool to redesign and improve the patient's path, focusing on access from the perspective of the Health Care Network ${ }^{(7-8)}$.

The political and financial consequences for organizations and governments when there are queues in emergency departments or operations are cancelled because beds are unavailable are relevant and high. However, above all, it is important to look at the physical and emotional costs to patients experiencing barriers to access $s^{(9)}$.

Due to its benefits, the Complexo Hospital de Clinicas (CHC), characterized as a public teaching and reference hospital in the city of Curitiba (Paraná), has a great demand for care, hospitalizations and surgeries. In compliance with the Policy and seeking to optimize bed management and increase the supply of beds, the Department of Health established the NIR. This service was named Bed Management and its activities started in 2015. Management nurses were hired and joined the team of this service as of January 2016.

There is a new scope of work for the category, which leads to some concerns regarding what are the activities that the management nurse performs in this service. For this reason, we sought a theoretical model that would provide elements to analyze the performance of nurses in this service.

Dubois' theoretical model, called Nursing Care Performance Framework (NCPF) ${ }^{(10)}$, consists of three nursing subsystems that operate together to achieve three functions: acquiring, deploying and maintaining nursing resources; transforming nursing resources into nursing services and producing changes in patients' condition as the result of the provision of nursing services. These subsystems are operationalized through dimensions composed of multiple components that define the structure, processes and results of the overall system. Within each subsystem, the components are involved in multiple processes of interaction to achieve a specialized function.

Therefore, it provides a comprehensive, integrated and theoretically based model. It encompasses the Donabedian triad, which provides the components and anatomy of the model structure; Parsons' social theory, which helps understanding the operating mechanisms and functions of each of these components; and Systems theory, which considers the linkages between these different components and the environmental factors influencing them. This model allows understanding the performance of nurses in a given service, as it assesses the care performance they provide ${ }^{(10)}$.

Given the above and considering Bed Management as an innovative field, which leads to the expansion of nurses'scope of practice, visibility and administrative experience and contributes to the optimization of hospital beds, this study has the following guiding question: How is nurses' performance in a Bed Management service?

\section{OBJECTIVES}

To analyze the performance of nurses in the Bed Management service of a public teaching hospital.

\section{METHODS}

\section{Ethical aspects}

The research was approved by the Research Ethics Committee involving Human Being of the Complexo Hospital de Clínicas of the Federal University of Paraná. The Informed Consent Term was signed by the participants, complying with the ethical precepts of resolution 466/2012, and the participant's identity was preserved by the use of codes.

\section{Type of study and Theoretical and Methodological Framework}

This is a descriptive, qualitative research that followed the criteria presented in the Consolidated Criteria for Reporting Qualitative Research (COREQ). The theoretical model that inspired this study is the Nursing Care Performance Framework, created by Dubois and collaborators ${ }^{(10)}$.

\section{Study setting}

The research was conducted at the Bed Management unit and care units of the Complexo Hospital de Clínicas. This is a large hospital that assists patients from all over the state of Paraná for outpatient, clinical and surgical treatment, with approximately 500 active beds. Bed Management works in afternoons, 7 days a week, with five nurses on a $12 \times 36$ hour scale. The nurses report to a medical coordinator for administrative/bureaucratic matters. This scope of work of this service is documented and validated by the Institution's Health Care Management.

\section{Data source}

Participants initially selected were nurses of the Bed Management service. In order to deepen the analysis of their performance in the service, nurses and doctors/residents who worked in the care units in afternoons were included, as this is the time of operation of the Bed Management service. Refusal to participate in the research and nonattendance to the interview after three appointments were considered as exclusion criteria. Five nurses of the Bed Management service, 21 nurses from the care units and six doctors/residents participated in this study, totaling 32 participants. 


\section{Data collection and organization}

Data was collected from February to May 2018. Initially, a nonparticipant observation of the nurses of the Bed Management service was carried out for a total of 28 hours. With the help of a field diary, the following aspects were observed: Nurses' performance; Interaction of the nurse with the other services; Physical, material and technological resources of the Bed Management service; and Difficulties in the work process, autonomy and decision-making process of the nurse in the service. The information was later entered in the program Microsoft Word version 2010.

The interviews followed a semi-structured script and were conducted by the researcher herself, with the following guiding questions: What motivates you in the work in Bed Management? What aspects of your work are related to your quality of life? How does your service integrate with the network? (guiding questions specific to the group of nurses in Bed Management). The questions that guided the interviews for all participants were: What kind of knowledge makes a nurse qualified to work in Bed Management? Describe the difficulties and advantages of the service? What services are involved with Bed Management? How does decision making occur in Bed Management? What were the results of the work of the nurses in Bed Management? How is the interface between the Bed Management nurse and the care unit? What are the activities performed by the Bed Management nurse? How does the Bed Management nurses use their autonomy at work? What are the professionals required in a Bed Management team?

The script was pilot tested in a Bed Management service in another hospital in the same city and was adjusted as needed. Before the interviews, the nursing coordination of each care unit, the Head of Bed Management and the Health Care Management were contacted. Afterwards, each participant was invited to participate in the research and informed about the objectives of the study. The interviews were scheduled at a place, date and time agreed between the researcher and the research participants. The interviews were recorded and transcribed in full.

The decision to terminate the interviews and the duration of the observations were determined by the saturation of the data, that is, when no other element was identified and no new information was necessary, as it would not change the understanding of the phenomenon ${ }^{(11)}$.

To complement the data collection, the records of Bed Management, such as the work scale, which included the workload and the nursing work team, were analyzed. The patient transfer forms in the Bed Management service, which were a work instrument of the nurse, allowed identifying the aspects evaluated, thus addressing the nurses' performance. Finally, the occupancy rate before and after the work of the Bed Management nurse at the hospital was used as a quantitative representation of the result of the work of this professional.

\section{Analysis of data}

The corpus of the interviews was analyzed with the MAXQDA software, according to the Theme/Category-Based Content Analysis (ACTC) technique ${ }^{(12)}$.

ACTC uses systematic and objective procedures to describe the content of messages, whether quantitative or qualitative. This allows the inference of knowledge regarding the conditions of production and reception (inferred variables) of these messages. Its fundamental principle is reducing data ${ }^{(12)}$.

This technique also presents the researcher's choice to resort to previously defined categories based on theoretical frameworks, which corresponded to the functions of Dubois theoretical model, arranged in three previously defined analysis matrices. The matrices present the set of RU (in parentheses) for each Meaning Unit (MU), which, in turn, expressed the meanings of the participants' statements. After this organization, the same process was followed for the observational and documentary data, which were added to the analysis matrix above, according to the content of the similar categories and in order to cross the data. To elucidate the contribution of data according to the collection technique, the different techniques are identified in parentheses distributed in the analysis matrix, as follows: Interviews (E), Non-participant observations (O) and Service records data (D).

The data were grouped and regrouped, extracting fragments with greater relevance and compressing information, until reaching the final version explained in the results of this research. A total of 496 Registration Units (RU) were obtained from the interviews, 21 from observations and four from the record of the Bed Management service (Charts 1, 2 and 3).

\section{RESULTS}

Regarding the characterization of the participants, the 21 nurses from the care units had a mean age of 41 years and mean professional experience of eight years. The five nurses in the Bed Management service had a mean of two years of experience in care and management. Six doctors/residents with a mean age of 28 years and mean work experience of three months participated in the research. This period of work experience can be explained by the fact that most participants in the medical category were in their first year of work and were responsible for the communication with bed management in the period of data collection. Most of the participants were female.

Data analysis allowed outlining the activities developed by nurses in Bed Management. These activities are presented in categories and subcategories from Dubois' theoretical model. The first category contains aspects related to the structure of the service, including human, material and physical resources and qualification of the professionals. Aspects related to difficulties, advantages, motivation and quality of life were also part of the nurses' performance in Bed Management, as presented in Chart 1.

The second category was related to aspects such as autonomy, decision making, support from services and managers and the activities performed by nurses in Bed Management, related with the subcategory environment and nursing work process, presented in Chart 2.

The third category was related to the results of the work of nurses in Bed Management. Aspects related to interface with other services, indicators such as occupancy rate and improved length of stay, changes in the organization's culture and optimization of beds were included in this category, as shown in Chart 3. 
Chart 1 - Category 1: Acquisition, implementation and maintenance of nursing resources, Curitiba, Paraná, Brazil, 2019

\begin{tabular}{|c|c|c|c|}
\hline \multicolumn{2}{|c|}{ AVAILABILITY OF NURSING STAFF, WORKING CONDITIONS AND MAINTENANCE OF THE NURSING TEAM } & \multirow{2}{*}{$\begin{array}{c}\begin{array}{c}\text { Total } \\
\text { number of } \\
\text { RUs / MU }\end{array} \\
26\end{array}$} & \multirow{2}{*}{\begin{tabular}{|c|}
$\begin{array}{c}\% \text { RUs / } \\
\text { MU }\end{array}$ \\
$8.7 \%$
\end{tabular}} \\
\hline $\begin{array}{l}\text { MU1 } \\
\text { Professionals required } \\
\text { in Bed Management }\end{array}$ & $\begin{array}{l}\text { Bed Management must be essentially composed of nursing professionals }(14)(E) \text {. Other professionals } \\
\text { were also mentioned, such as teams with nurses, doctors and social workers (12) (E). }\end{array}$ & & \\
\hline $\begin{array}{l}\text { MU2 } \\
\text { Qualification and } \\
\text { experience of } \\
\text { the nurse in Bed } \\
\text { Management }\end{array}$ & $\begin{array}{l}\text { To work in Bed Management, nurses must have knowledge of both management and care (30). For this, } \\
\text { they can use instruments such as the Fugulin Scale and Nursing Staffing, and must have a vision focused } \\
\text { on the financial sustainability of the hospital. The professional must have experience in management (6) } \\
\text { and experience in care (31). They must know how the flow and the units of the hospital work (23). The } \\
\text { knowledge the nurse acquires during their training - in technical-scientific courses and on the health- } \\
\text { illness process in nursing undergraduate courses - were considered sufficient to work in the service (6). } \\
\text { Qualification, at the level of graduation, was not considered as a requirement to work in this service (4). } \\
\text { However, the doctors and residents pointed out the need for training in management and care (2). The } \\
\text { nurse must have competences (3) such as: leadership, decision making and teamwork. Flexibility (10) } \\
\text { negotiation (7), proactivity (2), communication and agility (3), were also mentioned (E) }\end{array}$ & 127 & $42.3 \%$ \\
\hline $\begin{array}{l}\text { MU3 } \\
\text { Profile of patients in } \\
\text { the hospital }\end{array}$ & $\begin{array}{l}\text { The Bed Management nurse assesses the patient profile as criteria for bed allocation, seeing, for } \\
\text { example, if the patient is classified as elective, palliative, hospitalized for bone marrow transplantation, } \\
\text { or critical (2) (D) }\end{array}$ & 02 & $0.7 \%$ \\
\hline $\begin{array}{l}\text { MU4 } \\
\text { Physical, material } \\
\text { and technological } \\
\text { resources. }\end{array}$ & $\begin{array}{l}\text { It was observed that nurses use computer, telephone and pager. These resources are considered } \\
\text { essential for communication with other units and services. Regarding the structure, the space is } \\
\text { shared with other services, includes a bathroom and a kitchen, and is accessible, illuminated and } \\
\text { ventilated (1) (0) }\end{array}$ & 01 & $0.3 \%$ \\
\hline $\begin{array}{l}\text { MU5 } \\
\text { Workload and } \\
\text { organization of the } \\
\text { service }\end{array}$ & $\begin{array}{l}\text { Nurses in Bed Management work } 12 \times 36 \text { hour shifts, with one professional per shift (1) (D). The service } \\
\text { is organized by flow/itinerary, considering from entrance to the hospital to the other services involved } \\
\text { (1) (D). }\end{array}$ & 02 & $0.7 \%$ \\
\hline $\begin{array}{l}\text { MU6 } \\
\text { Difficulties }\end{array}$ & $\begin{array}{l}\text { Communication between Bed Management nurses, care nurses and resident physicians is fragile, } \\
\text { which is also related to their lack of knowledge about the transfer flow of patients in hospital beds (25) } \\
\text { (E, O). Another difficulty was the material and physical resources of the institution, such as isolation } \\
\text { beds and the great demand in contrast with the lack of beds in the hospital (25) (E, O). The clinical } \\
\text { profile of the patients admitted, which is incompatible with the care characteristics of the care unit, } \\
\text { was a weakness in the perspective of the care nurses (12) (E). The culture of the professionals in } \\
\text { the institution with their peers was mentioned by the Bed Management nurses as a barrier to their } \\
\text { performance in the service (4) (E). Aspects that lead to hospital discharge (5) (E), the work overload } \\
\text { of nurses in the healthcare units (4) (E), fragile medical support (3) (E) and access to previous patient } \\
\text { information (3) (E) were other fragilities that were pointed out (E). }\end{array}$ & 81 & $27 \%$ \\
\hline $\begin{array}{l}\text { MU7 } \\
\text { Advantages }\end{array}$ & $\begin{array}{l}\text { One advantage pointed out by the participants was the centralization of Bed Management in the } \\
\text { hands of the Bed Management nurse, that is, only one service is responsible for this activity ( } 22)(\mathrm{E}) \text {. } \\
\text { This makes allocation and/or transfer of patients quicker (10) }(\mathrm{E}, \mathrm{O}) \text {, since nurses have an overview of } \\
\text { hospital beds, while other professionals have a perspective limited to their unit/service (8) (E, O). The } \\
\text { nurse can improve the work process by reducing the number of empty beds (2) (E).x }\end{array}$ & 42 & $14 \%$ \\
\hline $\begin{array}{l}\text { MU8 } \\
\text { Aspects that lead to } \\
\text { quality of life and work } \\
\text { motivation from the } \\
\text { perspective of nurses } \\
\text { in Bed Management }\end{array}$ & $\begin{array}{l}\text { Personal satisfaction when meeting the patient's need and recognition of their work were important } \\
\text { motivations for nurses' work in Bed Management (8). Accidents, injuries and illnesses related to work } \\
\text { in Bed Management were not mentioned by the nurses of this service (5). Support from bosses, } \\
\text { colleagues and services involved was considered an aspect of quality of life, as it provides a fluid } \\
\text { working environment (3). For them, quality of life is also related to psychological preparation, as there } \\
\text { is communication with different professionals and conflict mediation is necessary (2). The availability } \\
\text { of resources to do the work was also mentioned (1) (E). }\end{array}$ & 19 & $6.3 \%$ \\
\hline \multicolumn{2}{|l|}{ Total } & 300 & $100 \%$ \\
\hline
\end{tabular}

Chart 2 - Transformation of nursing resources into nursing services, Curitiba, Paraná, Brazil, 2019

\section{ENVIRONMENT AND NURSING WORK PROCESS}

\section{MU1}

Autonomy of

the nurse in Bed

Management

MU2

Support from

colleagues and

managers and

integration between

services and the

network
The nurse has a limited autonomy (21). However, this autonomy exists mainly in the decision-making regarding the allocation of the patient (14). This is sometimes seen as an authoritarian autonomy by some nurses of the care unit (6). This autonomy is supported by the leadership and by the established flows (4). (E, O)

All hospital services were understood as support for nurses in Bed Management (22). Some of the services mentioned were diagnostic support (imaging and laboratory exams), Hospital Infection Control Service, Discharge Management, operational support, hospital management, and the Care Units (11). Bed Management is more integrated with the hospital's internal services and not so much with the Health Network itself; this interface occurs only in sporadic and specific cases $(7)(E, O)$.

\begin{tabular}{|c|c|}
$\begin{array}{c}\text { Total } \\
\text { number of } \\
\text { RUs / MU }\end{array}$ & $\begin{array}{c}\% \text { RUs / } \\
\text { MU }\end{array}$ \\
\hline 45 & $31.2 \%$ \\
40 & $27.9 \%$ \\
\hline
\end{tabular}

To be continued 


\begin{tabular}{|c|c|c|c|}
\hline \multicolumn{2}{|c|}{ ENVIRONMENT AND NURSING WORK PROCESS } & \multirow{2}{*}{$\begin{array}{c}\begin{array}{c}\text { Total } \\
\text { number of } \\
\text { RUs / MU }\end{array} \\
\\
37\end{array}$} & \multirow{2}{*}{\begin{tabular}{|c}
$\begin{array}{c}\% \text { RUs / } \\
\text { MU }\end{array}$ \\
$25.7 \%$
\end{tabular}} \\
\hline $\begin{array}{l}\text { MU3 } \\
\text { Decision-making } \\
\text { process of Bed } \\
\text { Management nurses }\end{array}$ & $\begin{array}{l}\text { Decision making is based on the clinical profile of patients, assessed by the Bed Management nurse } \\
\text { (17). From the perspective of care nurses, these decisions are shared between them (6). The patient } \\
\text { is allocated to an available bed (5), or allocated according to cases in which the patient is a priority, } \\
\text { such as critical patients and older adults (3) or the criteria is the transfer flow of the institution (2). } \\
\text { Discussion of cases within the management team (1) and scheduling of discharges (1) are also } \\
\text { considered. Some care nurses are unaware of how this decision-making occurs (2) (E) }\end{array}$ & & \\
\hline $\begin{array}{l}\text { MU4 } \\
\text { Performance of } \\
\text { the nurse in Bed } \\
\text { Management }\end{array}$ & $\begin{array}{l}\text { The nurses apply the Kanban Methodology and elaborate and implement strategies for resolution } \\
\text { when identifying extended length of hospital stay (8). They manage beds through inter-unit transfer } \\
\text { requests when allocating patients ( } 7) \text {. They work with bureaucratic issues, data collection for the } \\
\text { hospital census and generation of indicators such as the occupancy rate of the hospital. They fill out } \\
\text { spreadsheets and elaborate Standard Operating Procedure }(7)(E, O)\end{array}$ & 22 & $15.2 \%$ \\
\hline \multicolumn{2}{|l|}{ Total } & 144 & $100 \%$ \\
\hline
\end{tabular}

Chart 3 - Results of the work of the nurse in Bed Management, February to May 2018, Curitiba, Paraná, Brazil, 2019

\begin{tabular}{|c|c|c|c|}
\hline \multicolumn{2}{|c|}{ RESULTS OF THE WORK OF THE NURSE IN BED MANAGEMENT } & \multirow{2}{*}{$\begin{array}{c}\begin{array}{c}\text { Total } \\
\text { number of } \\
\text { RUs / MU }\end{array} \\
33\end{array}$} & \multirow{2}{*}{\begin{tabular}{|c|}
$\begin{array}{c}\% \text { RUs / } \\
\text { MU }\end{array}$ \\
$43 \%$ \\
\end{tabular}} \\
\hline $\begin{array}{l}\text { MU1 } \\
\text { Interface between } \\
\text { teams }\end{array}$ & $\begin{array}{l}\text { There is generally a good rapport between teams in terms of communication and relationship (33) } \\
(\mathrm{E}, \mathrm{O}) \text {. However, means of contact other than the telephone could be used for a more immediate } \\
\text { communication }(\mathrm{E}, \mathrm{O}) \text {. }\end{array}$ & & \\
\hline $\begin{array}{l}\text { MU2 } \\
\text { Patients' Length of } \\
\text { Stay }\end{array}$ & $\begin{array}{l}\text { Participants reported improvement in the length of stay of hospitalized patients (11). The concern } \\
\text { of the nurses to identify and take action in relation to the causes that kept patients hospitalized was } \\
\text { recognized by the nurses of the care units ( } 7 \text { ) (E) }\end{array}$ & 18 & $23.3 \%$ \\
\hline $\begin{array}{l}\text { MU3 } \\
\text { Improvement in } \\
\text { Occupancy Rate }\end{array}$ & $\begin{array}{l}\text { Participants reported improvement in occupancy rate as a result of nurses' work (10). Occupancy rate } \\
\text { had a } 5.73 \% \text { increase from } 2015 \text { to } 2017 \text {, according to data from the service (1) (E, D) }\end{array}$ & 11 & $14.2 \%$ \\
\hline $\begin{array}{l}\text { MU4 } \\
\text { Influence on culture } \\
\text { change in the hospital. }\end{array}$ & $\begin{array}{l}\text { The bed is seen by professionals as belonging to the hospital, and not intended for any medical } \\
\text { specialty, a fact that leads to bed turnover (6). For them, the service became a reference within the } \\
\text { institution (3) (E) }\end{array}$ & 09 & $11.7 \%$ \\
\hline $\begin{array}{l}\text { MU5 } \\
\text { Optimization of } \\
\text { hospital beds }\end{array}$ & $\begin{array}{l}\text { From the perspective of the nurse of the care unit, empirically, there has been an increase in the } \\
\text { number of hospital admissions that may lead to a reduction in patient waiting lines (5) (E) Up to two } \\
\text { thousand transfer requests for beds in the hospital have been done so far (1) (O) }\end{array}$ & 06 & $7.8 \%$ \\
\hline \multicolumn{2}{|l|}{ Total } & 77 & $100 \%$ \\
\hline
\end{tabular}

\section{DISCUSSION}

The performance of nurses was initially understood in this research in its relation with the structure/resources of the service. This is the first fundamental function of the nursing system, necessary to provide care. This structure can contribute or weaken the work process of this professional ${ }^{(10)}$.

The nurse was pointed out as the essential professional for the composition of the staff in Bed Management. This shows that nursing is considered important by peers and physicians/ residents of the institution. With the current scenario, characterized by increasing pressure on healthcare organizations to deliver higher performance with limited resources, it is essential to capitalize all existing resources. In this context, nursing is a significant resource, giving the number of nursing professionals in the workforce ${ }^{(13-14)}$. The literature points out that although the decision to admit and treat individual patients is the responsibility of doctors, it is nurses who are largely in charge of managing overall bed capacity, which values the performance of this professional ${ }^{(9)}$.

In the United Kingdom ${ }^{(9)}$, nurses have been increasingly enrolled in the Bed Management, and the work they do on a daily basis is relevant for the quality of patient care and the efficiency of the organization. However, their work was considered practically invisible, as their knowledge and skills went largely unexploited and their work had little influence on organizational strategy ${ }^{(9)}$.

In contrast, the findings of this research revealed the visibility of nurses in the institution. The recognition of the professional in the service can generate benefits for them and for the institution, since recognition is related to suffering and pleasure, which are associated with the maintenance of the mental health of workers within the work organization ${ }^{(15)}$. Maintaining this at work might have an impact on cost reduction in the institution ${ }^{(10)}$. Support from managers and colleagues refers to the perception of the degree to which the organization recognizes the contribution of nurses and is concerned about their well-being ${ }^{(16)}$. According to Dubois theoretical model, job satisfaction is related to the pleasure perceived by the professional in the workplace ${ }^{(17)}$.

The supply of nursing staff should be evaluated beyond the amount of staff available, that is, educational preparation, qualification and experience of these professionals should also be taken into consideration ${ }^{(10)}$. Highly qualified nurses are necessary to manage health systems and to relate to health teams and are fundamental to achieve better results for patients ${ }^{(18)}$. In addition to knowledge and experience in management, nurses with experience in care can obtain knowledge that facilitates 
the assessment of the patient care profile, which is considered important to manage beds in the hospital.

The process of restructuring the curriculum, approved by the National Nursing Curriculum Guidelines (DCNs/ENF), proposes adjusting the profile of the future nurse to match the current health context, so that the nurse can have a more integrated education, with practice associated with the health services network ${ }^{(19-20)}$. In this perspective, these professionals need skills and abilities such as: health care, decision making, communication, leadership, administration and management and continuing education ${ }^{(20)}$, consistent with the competences and abilities mentioned in this study.

The difficulties and advantages reported in this study are also conditioning factors for the performance of nurses' work, and communication is the most prominent factor. Effective communication as well as interpersonal skills are essential to ensure a positive patient care experience ${ }^{(21)}$.

The communication pointed out as fragile in this research was related to an unclear flow of patient allocation and transfer to care units. Weak communication is found in many health settings and is prominent in patient transfers and in places where rapid and effective management is indispensable ${ }^{(22)}$. However, even though there were reports of lost information between care nurses, bed management nurses and resident physicians, which was presented as a difficulty in the results of this research, communication was considered an advantage, as Bed Management information was centralized in this specific service, which led to more clear and agile communication.

When thinking about actions to improve communication or activities in general, it is essential to mention the use of technological devices to share information of a particular service. A study has identified indicators related to the use of Information and Communication Technologies (ICTs) using Dubois theoretical model. Among the indicators found are time management, information quality and access, nurse autonomy and collaboration, nurses' competencies and skills, and communication and care coordination ${ }^{(23)}$. These indicators are important for nursing reflection, which is related to improvement of attitude and the particularities of nursing in a highly technological world ${ }^{(24)}$.

Factors such as physical facilities, technologies, organizational configurations, and financial resources define the overall organization of nursing care and determine the extent to which nursing staff are able to perform their roles ${ }^{(10)}$. The scarcity of beds leads to cancellation of elective surgeries, delayed admission of patients, allocation to inappropriate beds, difficulties transferring patients between wards, delayed discharges from critical units, and increased length of hospital stay ${ }^{(25)}$.

Through the Kanban method, the nurse identifies the patient's length of stay and tries to implement actions that can solve cases of prolonged hospitalization ${ }^{(26)}$. Bed Management consists in organizing the allocation of new admissions to vacant beds, by means of real-time knowledge of the hospital census and of the demands for hospitalization. In addition, these professionals evaluate and implement actions to optimize the entire process, from admission to discharge ${ }^{(27)}$.

From the perspective of the theoretical model, the findings of this category revealed a broad set of dysfunctions and deficiencies, such as insufficient supply of material resources and gaps between nurse staffing and patients' needs, due to the difficulties detected ${ }^{(10)}$. Such deficiencies are considered as failures that do not involve the professional and do not result from direct contact with patients, but that may have potentially delayed consequences on both nursing care processes and outcomes ${ }^{(10)}$.

Effective stewardship of nursing resources, as described in the first category, is not an end state. A second key function of the nursing system is to transform available resources into nursing services that address patients' needs. Thus, it reflects not only the activities performed by nurses, but also the involvement of nursing managers in peer support to create an appropriate practice environment ${ }^{(10)}$.

Autonomy and decision making were considered important factors in the nursing environment. When nurses are able to exercise their clinical and organizational knowledge and skills via autonomous practice and decision making, they can drive improvements in care quality ${ }^{(13,16)}$. An example of this are the lower odds of 30-day mortality associated with greater nurses autonomy, even after accounting for patient risk and hospital characteristics $^{(13)}$.

Indicators of negative outcomes, such as extended length of stay, reflect failures that may have multiple causes and can originate from one or more systems ${ }^{(10)}$. Hence the importance of evaluating outcomes in the service, analyzing the professional's performance and, above all, listing strategies for solving issues identified. The findings of this study showed a series of good outcomes of the nurses' performance, for example, the Occupancy Rate increased by $5.73 \%$ from 2015 to 2017 , after the implementation of the service in the hospital. In addition, even if not represented in numbers, the improvement in the length of stay of patients in the institution is also significant, which reinforces the positive performance of the professional.

A study in the light of the "Donabedian triad" evaluating hospitals that implemented Bed Management in Porto Alegre corroborates these findings. The study found changes in the indicators after the implementation of the service in hospitals, with a similar increase in occupancy rate and a reduction in patients' length of stay ${ }^{(8)}$.

The findings of this study characterized the nurse's performance as a'bridge' between the hospital bed and the patient. Reflecting on actions developed by nurses with the patient is considered a prerequisite for developing and learning practical professional skills in nursing management ${ }^{(28-29)}$.

\section{Limitations of the study}

The main limitation of this study was that it was carried out in only one institution, with an approach focused only on a particular reality. However, the knowledge produced can support strategies for improving and changing the work process in the institution, and assist institutions that are implementing this service.

\section{Contributions to the area}

Bed Management was presented as an innovative field that contributes to nursing practice. 


\section{FINAL CONSIDERATIONS}

Bed Management is a complex service that involves the whole hospital in the work process, including operational support, hospitalization and direct patient care. The activities developed in this service follow a path with elements that encompass the patient and the hospital bed. The activities developed by nurses are reflected in the "performance" of these professionals.

The Nursing Care Performance Framework provided a comprehensive, integrated and theoretically based model that allowed for an analysis of the performance of the overall nursing system, recognizing the structure and resources, the work process and reflecting on the results achieved, giving an overview of the role of nurses in Bed Management. This approach broadens the view of nursing performance, in a multidimensional perspective that encompasses the various aspects of nursing, whether in direct patient care, administrative and managerial activities and in the training for the profession.

\section{FUNDING}

This work was carried out with the support of the Coordination for the Improvement of Higher Education Personnel - Brazil (Capes) - Funding Code 001 (Scholarship holder) and Supported by Conselho Nacional de Desenvolvimento Científico e Tecnológico (CNPq), Brazil, grant number 406058/2016-4.

\section{REFERENCES}

1. Salway RJ, Valenzuela R, Shoenberger JM, Mallon WK, Viccellio A. Emergency department (ed) overcrowding: evidence-based answers to frequently asked questions. Rev Médica Clínica Las Condes. 2017,28:213-19. doi: 10.1016/j.rmclc.2017.04.008

2. Richardson J. What's really happening with hospital bed numbers?. BMJ. 2017,358:j4439. doi: 10.1136/bmj.j4439

3. Tampubolon L, Pujiyanto. Bed management strategy for overcrowding at the emergency department: a systematic review. KnE Life Sciences, 2, 2017, Dubai. Anais. Dubai: International Conference on Hospital Administration. 2017:50-9. doi: 10.18502/kls.v4i9.3557

4. Goldwasser RS, Lobo MSC, Arruda EF et al. Difficulties in access and estimates of public beds in intensive care units in the state of Rio de Janeiro. Rev Saúde Pública. 2016,50:19. doi: 10.1590/S1518-8787.2016050005997

5. Claret PG. Boudemaghe T, Bobbia X. Consequences for overcrowding in the emergency room of a change in bed management policy on available in-hospital beds. Australian Health Review. 2015;40(4):466-72. doi: 10.1071/AH15088

6. Aguilar-Escobar V, Bourqueb S, Godino-Gallegoc N. Hospital kanban system implementation: Evaluating satisfaction of nursing personnel. Investig Europeas Direc Econ Empresa. 2015;21(3):101-10. doi: 10.1016/j.iedee.2014.12.001

7. Ministério da Saúde (BR). Portaria n ${ }^{3}$ 3.390, de 30 de dezembro de 2013. Institui a Política Nacional de Atenção Hospitalar (PNHOSP) no âmbito do Sistema Único de Saúde (SUS), estabelecendo- se as diretrizes para a organização do componente hospitalar da Rede de Atenção à Saúde (RAS) [Internet]. 2013 [citado 2019 Jan 20]. Available from: http://bvsms.saude.gov.br/bvs/saudelegis/gm/2013/prt3390_30_12_2013.html

8. Soares VS. Análise dos Núcleos Internos de regulação hospitalares de uma capital. Einstein [Internet] 2017 [cited 2019 Abr 25];15(3):339-43. Available from: http://apps.einstein.br/revista/arquivos/PDF/3878-339-343-Analise-dos-Nucleos-Internos-de-Regulacao-hospitalares.pdf

9. Allen D. Inside 'bed management': ethnographic insights from the vantage point of UK hospital nurses. Sociol Health IIIn. 2015;37(3):370-84. doi: $10.1111 / 1467-9566.12195$

10. Dubois CA, D'Amour D, Pomey MP, Girard F, Brault I. Conceptualizing performance of nursing care as a prerequisite for better measurement: a systematic and interpretive review. BMC Nursing. 2013;12(7). doi: 10.1186/1472-6955-12-7

11. Nascimento LCN, Souza TV, Oliveira ICS, Moraes JRMM, Aguiar RCB, Silva LF. Theoretical saturation in qualitative research: an experience report in interview with schoolchildren. Rev Bras Enferm. 2018 Jan/Feb; 71(1):228-33. doi: 10.1590/0034-7167-2016-0616

12. Oliveira DC. Análise de Conteúdo Temático-Categorial: uma técnica maior nas pesquisas qualitativas. In: Lacerda MR, Costenaro RGS. Metodologias da pesquisa para a enfermagem e saúde: da teoria à prática. Porto Alegre: Moriá, 2015, 511p.

13. Rao AD, Kumar A, Mchugh M. Better Nurse Autonomy Decreases the Odds of 30-Day Mortality and Failure to Rescue. Nurs Scholarsh. 2017;49(1):73-9. doi:10.1111/jnu.12267.

14. Cassiani SHB, Lira Neto JCG. Perspectivas da Enfermagem e a Campanha Nursing Now. Rev Bras Enferm. 2018; 71 (5): 2351 - 52. doi: 10.1590/00347167.2018710501

15. Amorim LKA. Souza NVDO, Pires AS, Ferreira ES, Souza MB, Vonk ACRP. O trabalho do enfermeiro: reconhecimento e valorização profissional na visão do usuário. Rev Enferm UFPE. 2017;11(5):1918-25. doi:10.5205/reuol.11077-98857-1-SM.1105201722

16. Trudeau-aubin J. L'optimisation de la performance des services infirmiers: miser sur despratiques de gestion utilisées par les organisations hautement performantes [Dissertation]. Universitè de Montréal. Faculté des sciences infirmières [Internet]. 2015; 91 p; [cited 2019 jan 10]. Available from: http://hdl.handle.net/1866/13135

17. Yang J, Liu Y, Huang C, Zhu L. Impact of empowerment on professionnal practice environements and organizational commitment among nurses: a structural equation approach. Int J Nurs Pract. 2013;19(Suppl 1):44-55. doi: 10.1111/ijn.12016

18. Barbosa DVS, Barbosa NB, Najberg E. Regulação em Saúde: desafios à governança do SUS. Cad Saúde Colet. 2016;24(1):49-54. doi: 10.1590/1414-462X201600010106 
19. Ingwell-spolan C. Chief Nursing Officers'Views on Meeting the Needs of the Professional Nurse: How This Can Affect Patient Outcomes. Healthcare (Basel). 2018;6(2):56. doi: 10.3390/healthcare6020056

20. Leal JAL, Melo CMM. The nurses' work process in different countries: an integrative review. Rev Bras Enferm. 2018;71(2):413-23. doi: 10.1590/0034-7167-2016-0468

21. Ministério da Educação (BR). Conselho Nacional de Educação. Câmara de Educação Superior. Resolução CNE/CES n 3, de 07 de novembro de 2001. Institui Diretrizes Curriculares Nacionais do Curso de Graduação em Enfermagem [Internet]. Diário Oficial da União. Brasília, DF, 08 nov. 2001 [cited 2019 Jan 20]. Available from: http://www.cofen.gov.br/resoluo-cne-ces-n-3-de-7-de-novembro-de-2001-diretrizesnacionais-curso-graduaao-enfermagem_6933.html.

22. Webb L. Exploring the characteristics of effective communicators in healthcare. Nurs Stand. 2018;33(9):47-51. doi: 10.7748/ns.2018.e11157.

23. Müller M, Jürgens J, Redaèlli, M. Impact of the communication and patient hand-off tool SBAR on patient safety: a systematic review. BMJ Open. 2018;8(8):e022202. doi: 10.1136/bmjopen-2018-022202

24. Rouleau G, Gagnon MP, Côté J. Impact of Information and Communication Technologies on Nursing Care: Results of an Overview of Systematic Reviews. J Med Internet Res. 2017;19(4):e122. doi: 10.2196/jmir.6686

25. Fernandes MNF, Esteves RB, Teixeira CAB, Gherardi-Donato ECS. O presente e o futuro da Enfermagem no Admirável Mundo Novo. Rev Esc Enferm. USP. 2018;52:e03356. doi: 10.1590/s1980-220×2017031603356

26. Faria E, Costa Karl KRA, Santos MA, Fumio MK. Nova abordagem de gerenciamento de leitos associada à agenda cirúrgica. Rev Adm Saúde [Internte] 2010 [cited 2019 Jan 15];12(47):63-70. www.cqh.org.br/portal/pag/anexos/baixar.php?p_ndoc=207\&p_nanexo=286

27. Mitka E. Application of kanban system on a hospital pharmacy. Hell J Nucl Med [Internet]. 2015 [cited 2019 Jan 14];1:4-10. Available from: https://www.ncbi.nlm.nih.gov/pubmed/26665205

28. Ewertsson M, Bagga-Gupta S, Allvin R, Blomberg K. Tensions in learning professional identities: nursing students' narratives and participation in practical skills during their clinical practice: an ethnographic study. BMC Nurs. 2017;16:48. doi: 10.1186/s12912-017-0238-y

29. Moraes VCO, Spiri WC. Development of a journal club on the Nursing management process. Rev Bras Enferm. 2019;72(Suppl 1):221-7. doi: 10.1590/0034-7167-2018-0019 